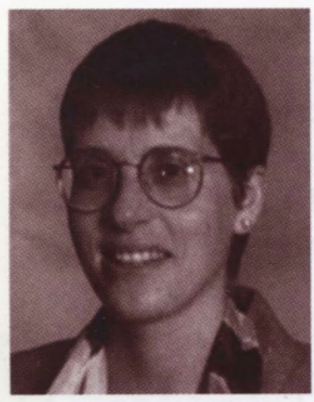

Professor Sue Arrowsmith

\title{
Professor Sue Arrowsmith
}

\author{
Director of the Public Procurement Research Group within Nottingham \\ University's School of Law.
}

The success of the Public Procurement Research Group within Nottingham University's School of Law is an example of the important role an academic institution can play at the heart of an emerging legal discipline. Public procurement is the purchase by government of works, goods and services, and it forms a significant part of the national economies of European countries (particularly the UK). At European level it is overseen by a number of directives which regulate matters such as the publication of future contracts, award procedures and criteria, enforcement measures, and measures to ensure a competitive bidding process.

On 6-7 September this year the PPRG is staging "Public procurement: global revolution II", an international conference which follows up a previous event on the same topic held in 1997. Issues in government procurement regulation will be examined, including WTO matters, the EU's procurement rules, electronic procurement, tackling corruption, enforcing procurement rules, procurement in developing countries, and new approaches to regulation. The importance of the event is endorsed by the presence of speakers from organisations including the WTO, the World Bank, the European Commission and various national governments.

The PPRG is closely identified with its Director, Professor Sue Arrowsmith. Originally established in 1996 at the University of Wales, Aberystwyth, where Sue Arrowsmith was Professor of Law, the Group moved with her in 1998 to the School of Law at the University of Nottingham. Professor Arrowsmith has done much to stimulate awareness of public procurement law, publishing a number of books including the Law of Public and Utilities Procurement (Sweet \& Maxwell, 1996) and numerous articles.

She edits the Public Procurement Law Review, along with other members of the PPRG, and has delivered numerous papers at conferences all over the world. Professor Arrowsmith is a member of the European Advisory Commission's Advisory Committee for the Opening up of Public Procurement, and a founding committee member of the United Kingdom Association for Regulated Procurement. Her teaching interests include world trade law and constitutional/administrative law, and her research topics take in governmental liability as well as public procurement itself.
The aim of the PPRG is to promote understanding of public procurement law by undertaking and publishing research, providing professional and academic training, organising conferences, and supporting excellence and best practice through consultancy and advice services. It liaises closely with outside organisations, and is sponsored by Achilles Information, solicitors Bevan Ashford, and the Chartered Institute of Purchasing and Supply.

An extensive research programme is conducted by the Group, and public procurement law can be studied on the LL.M programme. Students can study half modules devoted to the subject, and take modules related to public procurement including the world trading system, EU regulation of state intervention in the market, European external relations law, EC competition law and EU law. Supervision is also available for those wishing to undertake research in public procurement law towards the degrees of Ph.D and M.Phil, and scholarships are sometimes available. The Group's contacts with international organisations and private business are used to help students find placements. (2)

\section{Julian Harris}

Senior Information Officer, IALS

\section{CURRICULUM VITAE}

BA (Oxon) 1983; D.Jur. (Osgoode Hall) 1987, Gibbs, Winter Wms, Prizes 1982, Wronker Prize 1983, Commonwealth School 1984-87; Tutor in Law 1987-88, Lecturer in Law 1988-91, Professor of Law 1991-98, University of Wales, Aberystwyth; Professor of Law, University of Nottingham, 1998-; Director of the Public Procurement Research Group; Books include Government Procurement in the WTO (anticipated late 2001), Regulating Public Procurement: National and International Perspectives (2000), Public Private Partnerships and PFI (2000), Public Procurement: Global Revolution (1998), The Law of Public and Utilities Procurement (1996), Remedies for Enforcing the Public Procurement Rules (1993), A Guide to the Procurement Cases of the Court of Justice (1992) and Govermment Procurement and Judicial Review (1988); Recent articles include "The Community's legal framework on public procurement: the way forward at last", (1999) 36 Common Market Law Review, 13-49; "Framework purchasing and qualification lists under the European Directives: Part 1 (1999) 8 Public Procurement Law Review 115-46, "Rammerknotrakter I henhold til EU's Direktiver" (1999) 3 Nyt Fra 1. 